\title{
A suite of recombinant luminescent bacterial strains for the quantification of bioavailable heavy metals and toxicity testing Angela Ivask*, Taisia Rõlova and Anne Kahru
}

\author{
Address: Laboratory of Molecular Genetics, National Institute of Chemical Physics and Biophysics, Akadeemia tee 23, Tallinn, Estonia \\ Email: Angela Ivask* - angela@kbfi.ee; Taisia Rõlova - Taisia.Rolova@uku.fi; Anne Kahru - anne.kahru@kbfi.ee \\ * Corresponding author
}

Published: 8 May 2009

BMC Biotechnology 2009, 9:4| doi:|0.|| |86/|472-6750-9-4 |
Received: 19 September 2008

Accepted: 8 May 2009

This article is available from: http://www.biomedcentral.com/I472-6750/9/4 I

(c) 2009 Ivask et al; licensee BioMed Central Ltd.

This is an Open Access article distributed under the terms of the Creative Commons Attribution License (http://creativecommons.org/licenses/by/2.0), which permits unrestricted use, distribution, and reproduction in any medium, provided the original work is properly cited.

\begin{abstract}
Background: Recombinant whole-cell sensors have already proven useful in the assessment of the bioavailability of environmental pollutants like heavy metals and organic compounds. In this work 19 recombinant bacterial strains representing various Gram-positive (Staphylococcus aureus and Bacillus subtilis) and Gram-negative (Escherichia coli, Pseudomonas fluorescens) bacteria were constructed to express the luminescence encoding genes luxCDABE (from Photorhabdus luminescens) as a response to bioavailable heavy metals ("lights-on" metal sensors containing metalresponse elements, 13 strains) or in a constitutive manner ("lights-off" constructs, 6 strains).
\end{abstract}

Results: The bioluminescence of all 13 "lights-on" metal sensor strains was expressed as a function of the sub-toxic metal concentrations enabling the quantitative determination of metals bioavailable for these strains. Five sensor strains, constructed for detecting copper and mercury, proved to be target metal specific, whereas eight other sensor strains were simultaneously induced by $\mathrm{Cd}^{2+}$, $\mathrm{Hg}^{2+}, \mathrm{Zn}^{2+}$ and $\mathrm{Pb}^{2+}$. The lowest limits of determination of the "lights-on" sensor strains for the metals tested in this study were $\left(\mu \mathrm{I} \mathrm{I}^{-1}\right): 0.002$ of $\mathrm{CH}_{3} \mathrm{HgCl}, 0.03$ of $\mathrm{HgCl}_{2}, 1.8$ of $\mathrm{CdCl}_{2}, 33$ of $\mathrm{Pb}\left(\mathrm{NO}_{3}\right)_{2}, 1626$ of $\mathrm{ZnSO}_{4}, 24$ of $\mathrm{CuSO}_{4}$ and 340 of $\mathrm{AgNO}_{3}$. In general, the sensitivity of the "lightson" sensor strains was mostly dependent on the metal-response element used while the selection of host bacterium played a relatively minor role. In contrast, toxicity of metals to the "lights-off" strains was only dependent on the bacterial host so that Gram-positive strains were remarkably more sensitive than Gram-negative ones.

Conclusion: The constructed battery of 19 recombinant luminescent bacterial strains exhibits several novel aspects as it contains i) metal sensor strains with similar metal-response elements in different host bacteria; ii) metal sensor strains with metal-response elements in different copies and iii) a "lights-off" construct (control) for every constructed recombinant metal sensor strain. To our knowledge, no Gram-positive metal sensor expressing a full bacterial bioluminescence cassette (luxCDABE) has been constructed previously.

\section{Background}

The use of microbial cells for ecotoxicological analysis as well as for the toxicological screening of various chemicals is increasing. A variety of whole-cell sensors based on nat- ural or genetically modified microbes has been developed for this purpose. In general, there are two strategies for developing such microbial sensors: one utilizes microbes expressing the reporting signal e.g., bioluminescence con- 
stitutively ("lights-off" bacterial strains) and the other in chemical/effect-induced manner ("lights-on" sensors). The "lights-off" bacterial strains have been extensively used for toxicity testing of pure compounds as well as environmental samples [1,2] already for decades. The most popular such tests are Microtox ${ }^{\circledast}$, BioTox ${ }^{\mathrm{TM}}$, LUMIStox $^{\mathrm{TM}}$, ToxAlert ${ }^{\mathrm{TM}}$, which measure the effect of the sample on the luminescence of a naturally bioluminescent bacterium Vibrio fischeri [3].

"Lights-on" sensors are usually recombinant microbial cells containing a metal-response unit (traditionally a transcriptional regulator and its controlled promoter) fused to a promoterless reporter gene encoding for the reporting signal. Upon the presence of a bioavailable compound of interest (heavy metal or an organic compound/group of compounds), its entrance to the sensor cell and subsequent binding to the transcriptional regulator the expression of a reporter gene will take place. $\beta$ galactosidase, GFP and bioluminescence (the most favourable) have been used most often for reporter applications (reviewed in [4]). For environmental applications, LuxCDABE (a whole bacterial gene cassette required for the production of bioluminescence) is the most suitable reporter, primarily due to rapidity and ease of use. The first recombinant luminescent "lights-on" sensors were constructed in 1991 for naphthalene [5] and mercury [6]. Since then, a number of papers on bacterial strains "sensing" inorganic substances (mainly heavy metals or metalloids) but also organic compounds (e.g., benzene and its derivatives, naphthalene, polychlorinated biphenyls) have been published (reviewed in $[4,7]$ ). Currently, recombinant bacterial "lights-on" heavy metal sensors expressing bacterial bioluminescence system as a reporter include sensors for $\mathrm{Cd}, \mathrm{Pb}$ [8], $\mathrm{Hg}$ [8-12], $\mathrm{Cr}$ [8], Ni, Co [13], $\mathrm{Zn}, \mathrm{Cu}[8,14,15]$ and As [16]. In most of these sensors, the bioluminescence-encoding genes from Vibrio fischeri (that may become labile in temperatures above $30^{\circ} \mathrm{C} \mathrm{[4]} \mathrm{and} \mathrm{thus,} \mathrm{restrict} \mathrm{testing)} \mathrm{has} \mathrm{been} \mathrm{used.} \mathrm{Most} \mathrm{of}$ these papers describe just a few sensors that are often based on Escherichia coli $[9,10,12,14]$ orsome other Gramnegative bacterium from the genera Pseudomonas or Alcaligenes $[8,11,13,15]$ as a host. Thus, Gram-positive bacteria have rarely been used as hosts and no Gram-positive metal sensors expressing luxCDABE as a reporter have been constructed so far.

The recombinant luminescent sensor bacteria have been used for the assessment of bioavailable (the fraction entering the cells and inducing bioluminescence) metals from soils or water bodies $[8,11,13,15,17]$. However, due to the complexity of the environmental samples (colour, turbidity, mixed pollution) and the sensitivity of the used reporter system (bioluminescence is closely related to the energetic status of the cell [18]), several researchers $[13,17,19-24]$ have recognized the need for relevant con- trols which enable accounting for unspecific effects of the sample. This paper reports on the development of a battery of recombinant bioluminescent bacterial heavy metal "lights on" sensors accompanied by corresponding bioluminescent non-specific "lights off" control strains.

\section{Results \\ Luminescent Gram-negative strains}

Escherichia coli-based strains

Escherichia coli is an enteric Gram-negative bacterium with the sequenced genome [25], well developed methods for genetic modification [26] and various laboratory strains available. Although the relevance of this bacterium for environmental testing is questionable, it has been widely used in the construction of various bacterial sensors $[9,10,12,14,17]$, mainly due to its compatibility with the chemical-response elements used.

In total three new E. coli MC1061 recombinant luminescent sensor strains expressing luxCDABE genes in response to subtoxic concentrations of bioavailable heavy metals ("lights-on" sensors) were constructed: E. coli MC1061(pmerR ${ }_{\mathrm{BS}}$ BPmerlux), E. coli MC1061(pSLcueR/ pDNPcopAlux) and E. coli MC1061(pSLzntR/pDNPzntAlux) (Table 1). All the strains harbour plasmid(s) containing metal-response elements from resistance systems for $\mathrm{Hg}$ (from Serratia marcescens plasmid [27]; mer), Cu (cue/cop) and Zn (znt) (both from E. coli chromosome $[28,29])$ fused with the luxCDABE cassette [see Additional file 1]. MC1061(pSLcueR/pDNPcopAlux) and MC1061(pSLzntR/pDNPzntAlux) contain two plasmids necessary for sensor function, of which one (pSLzntR or pSLcueR, respectively) is present in bacterial cells in high copy number and contains genes for the regulatory proteins (cueR or $z n t R$ ). The other plasmid (pDNPzntAlux or pDNPcopAlux, respectively) present in medium copy number contains the lux-genes fused to a promoter (PcopA or PzntA) controlled by the regulatory proteins. Location of the genes for regulatory protein and the corresponding promoter in different plasmids yields high regulatory protein to promoter ratio necessary to reduce the unfavourably high level of leakage of the PcopA and PzntA and thus, high background luminescence of those strains (Table 1). Characteristics (number of cells in the test, background luminescence, maximum induction) of the constructed sensors are presented in Table 1. Induction profiles of those sensor strains with seven tested heavy metals are presented in Figure 1 and resepective limits of determination in Table 1.

In parallel with sensors, two E. coli toxicity control ("lights-off") strains: MC1061(pSLlux) and MC1061(pDNlux) were constructed (Table 1). These constitutively luminescent strains lacking metal-response elements contain plasmids in which the luxCDABE genes were either under the lac promoter (pSLlux) or T7 pro- 
Table I: Characteristics of Escherichia coli MCI06I-based luminescent heavy metal sensors and toxicity control strains

\begin{tabular}{|c|c|c|c|c|c|}
\hline & \multicolumn{3}{|c|}{ Sensor strains } & \multicolumn{2}{|c|}{ Control strains } \\
\hline & 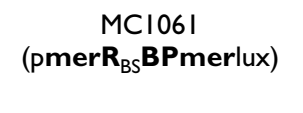 & $\begin{array}{c}\text { MCI06I } \\
\text { (pSLzntR/ } \\
\text { pDNPzntAlux) }\end{array}$ & $\begin{array}{l}\text { MCI06I (pSLcueR/ } \\
\text { pDNPcopAlux) }\end{array}$ & $\begin{array}{l}\text { MCI06I } \\
(\text { pSLlux) }\end{array}$ & 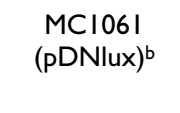 \\
\hline $\begin{array}{l}\text { Background } \\
\text { luminescence }\end{array}$ & $230 \pm 90$ & $2940 \pm 930$ & $520 \pm 70$ & $575000 \pm 35200$ & $6500 \pm 2270$ \\
\hline Maximum induction ${ }^{d}$ & 400 & 20 & 100 & no induction & no induction \\
\hline $\begin{array}{l}\text { No of cells in the test } \\
(100 \mu \mathrm{l})\end{array}$ & $4 \times 10^{7}$ & $10^{7}$ & $8 \times 10^{6}$ & $8 \times 10^{6}$ & $10^{7}$ \\
\hline Compound & \multicolumn{3}{|c|}{ Limit of determinatione/Toxicity ${ }^{f}, M$ (mg of compound $\mathrm{I}^{-1}$ ) } & $\begin{array}{l}\text { Toxicity }\left(2-\mathrm{h} \mathrm{EC}_{\left.50^{\mathrm{g}}\right),}, \mathrm{M}\right. \\
\left(\mathrm{mg} \text { of compound } \mathrm{I}^{-1}\right)\end{array}$ & \\
\hline $\mathrm{HgCl}_{2}$ & $\begin{array}{c}10^{-10}(0.00003) / 5 \\
(1.4)\end{array}$ & $8 \times 10^{-8}(0.02) / 10^{-5}(2.7)$ & no induction & $10^{-6}(0.4)$ & $10^{-6}(0.4)$ \\
\hline $\mathrm{CH}_{3} \mathrm{HgCl}$ & $\begin{array}{c}8 \times 10^{-12}(0.000002) / 5 \times \\
10^{-8}(0.01)\end{array}$ & not tested & not tested & $3 \times 10^{-6}(0.7)$ & not tested \\
\hline $\mathrm{CdCl}_{2}$ & $\begin{array}{c}3 \times 10^{-7}(0.06) / 5 \times 10^{-4} \\
(92)\end{array}$ & $\begin{array}{c}10^{-8}(0.003) / 5 \times 10^{-6} \\
(0.9)\end{array}$ & no induction & $4 \times 10^{-4}(70)$ & $2 \times 10^{-4}(31)$ \\
\hline $\mathrm{ZnSO}_{4}{ }^{\mathrm{h}}$ & no induction & $\begin{array}{c}5 \times 10^{-6}(0.8) / 5 \times 10^{-2} \\
(8000)\end{array}$ & no induction & $10^{-2}(1600)$ & $4 \times 10^{-3}(640)$ \\
\hline $\mathbf{P b}\left(\mathrm{NO}_{3}\right)_{2}$ & no induction & $7 \times 10^{-7}(0.2) / 10^{-3}(330)$ & no induction & $2.4 \times 10^{-4}(79)$ & $6 \times 10^{-4}(190)$ \\
\hline $\mathrm{CuSO}_{4}{ }^{\mathrm{i}}$ & not tested & not tested & $10^{-7}(0.02) / 10^{-3}(240)$ & not tested & $5.4 \times 10^{-4}(86)$ \\
\hline $\mathrm{AgNO}_{3}$ & not tested & not tested & $2 \times 10^{-6}(0.3) / 10^{-5}(2.6)$ & not tested & $2 \times 10^{-6}(0.3)$ \\
\hline
\end{tabular}

a control for MCI06I (pmerR $\mathbf{R}_{\mathrm{BS}}$ BPmerlux)

b control for MCI06I (PSLcueR/pDNPcopAlux) and MCI06I (pSLzntR/pDNPzntAlux)

c luminescence (relative light units, RLU) of $100 \mu \mathrm{l}$ of bacterial suspension before the test as measured by plate luminometer Fluoroskan

(ThermoLabsystems). Average of at least three assays

$\mathrm{d}$ as fold over the (non-induced) background

e see equation 4 in Methods

$f$ the lowest tested concentration causing a measurable decrease in the bioluminescence of the sensor strains (read from concentration-induction curves in Figure I)

$\mathrm{g}$ concentration causing $50 \%$ decrease in bioluminescence production (calculated from Figure 2)

h tested as $\mathrm{ZnSO}_{4} \times 7 \mathrm{H}_{2} \mathrm{O}$

i tested as $\mathrm{CuSO}_{4} \times 5 \mathrm{H}_{2} \mathrm{O}$

moter (pDNlux). Indeed, within the limits of error, the control strains were not induced by the heavy metals (Figure 2) and inhibition of bioluminescence (NL) was observed with increasing metal concentrations. Toxicity (2-h $\mathrm{EC}_{50}$ values) of the seven tested heavy metals to $E$. coli MC1061(pSLlux) and MC1061(pDNlux) are presented in Table 1 and respective concentration-effect curves (used for $\mathrm{EC}_{50}$ calculation) in Figure 2.

Pseudomonas fluorescens - based strains

Pseudomonas fluorescens is a non-pathogenic saphrophyte, which inhabits soil, water and plant surface, often bearing the ability to degrade various pollutants and is thus a very relevant organism for environmental analysis. P. fluorescens has been used as a test organism for general toxicity [30] as well as a host bacterium for constructed recombinant sensors for mercury, arsenic [19], copper [31] but also for phenolic compounds [32].

In the current study eight recombinant luminescent $P$. fluorescens OS8-based sensor strains were constructed
(Tables 2 and 3). Three strains: OS8(pDNmerR ${ }_{\mathrm{BS}}$ BPmerlux), OS8(pDNpbrRPpbrAlux) and OS8(pDNcadRPcadAlux) contained the sensor and reporter elements on a plasmid (about 10 copies per cell) and five sensor strains: OS8::KnmerR ${ }_{\mathrm{BS}}$ BPmerlux, OS8:: KncueRPcopAlux, OS8::KnzntRPzntAlux, OS8::KnpbrRPpbrAlux and OS8::KncadRPcadAlux contained the sensor and reporter elements as a single chromosomal insertion. The heavy metal response elements used originated from resistance systems for $\mathbf{H g}$ (from Serratia marcescens plasmid [27]; mer), Pb (from Ralstonia metallidurans CH34 plasmid pMOL30 [33]; pbr), Cd (from Pseudomonas putida choromosome [34]; cad), Cu (cue/cop) and Zn (znt) (both from E. coli chromosome [28,29]) [see Additional file 1]. The sensors are characterized in Tables 2 and 3 and their induction profiles with selected heavy metals shown in Figure 1.

In addition to sensors, two toxicity control ("lights-off") strains were constructed (Tables 2 and 3). One of these, P. fluorescens OS8(pDNlux), contained the luxCDABE cas- 


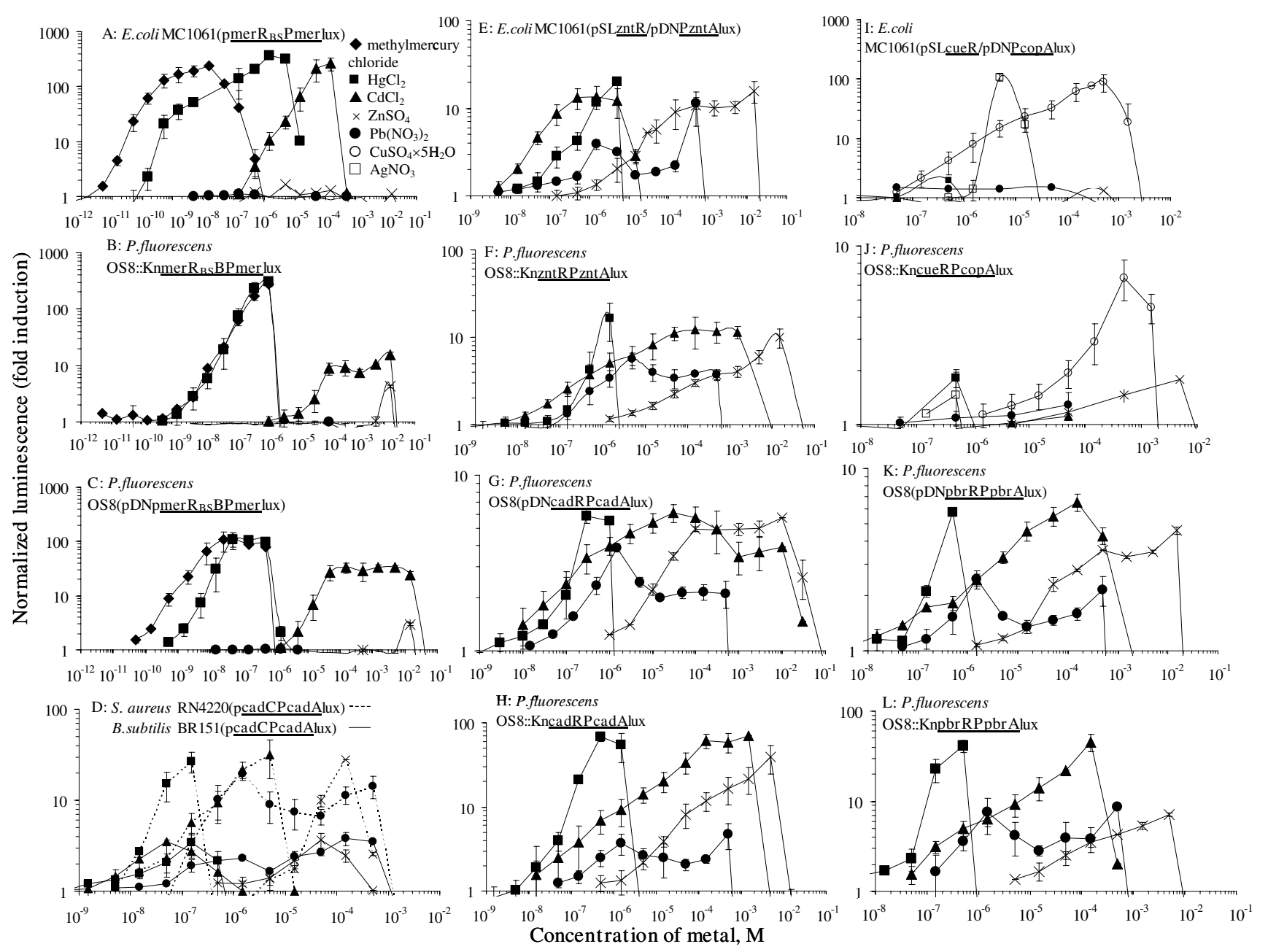

Figure I

Induction of luminescence (expressed as normalized luminescence) by heavy metals in different sensor strains. Names of sensors and symbols for heavy metals are indicated. Data represent mean \pm SD of three independent measurements.

sette under the $\mathrm{T} 7$ promoter on a plasmid and the other, P. fluorescens OS8::lux, contained the luxCDABE under the lac promoter as a chromosomal insertion. In both strains the bioluminescence was constitutive as within the limits of error they were not induced by the heavy metals (Figure 2). Toxicity (2-h EC50 values) of the tested metals to P. fluorescens OS8(pDNlux) and OS8::lux are presented in Tables 2 and 3 and respective concentrationeffect curves in Figure 2.

\section{Luminescent Gram-positive strains}

Bacillus subtilis and Staphylococcus aureus were used to construct Gram-positive heavy metal sensor strains. Bacillus subtilis is a spore-forming bacterium common in soils and thus a relevant environmental test organism. Recombinant B. subtilis has earlier been used as a model Grampositive bacterium for toxicity testing [35] as well as a host for a recombinant bacterial cadmium sensor [36]. Staphy- lococcus aureus, although not an environmentally relevant bacterium, it may be a medically important model organism as it is an opportunistic human pathogen often bearing multiple antibiotic resistance.

Two Gram-positive sensor strains, $S$. aureus RN4220(pcadCPcadAlux) and B. subtilis BR151(pcadCPcadAlux), in which the luxCDABE genes were under the control of heavy metal-inducible cadC-PcadA system from $S$. aureus plasmid pI258 [36] were constructed. The luxCD$A B E$ genes used were modified from Photorhabdus luminescens by optimizing the codon usage and ribosome binding sites for Gram-positive bacteria [37]. The constructed sensors are characterized in Table 4 and their induction profiles with $\mathrm{Hg}^{2+}, \mathrm{Cd}^{2+}, \mathrm{Pb}^{2+}, \mathrm{Zn}^{2+}$ are presented in Figure 1.

Two constitutively luminescent Gram-positive control ("lights-off") strains S. aureus RN4220(p602/22lux) and 

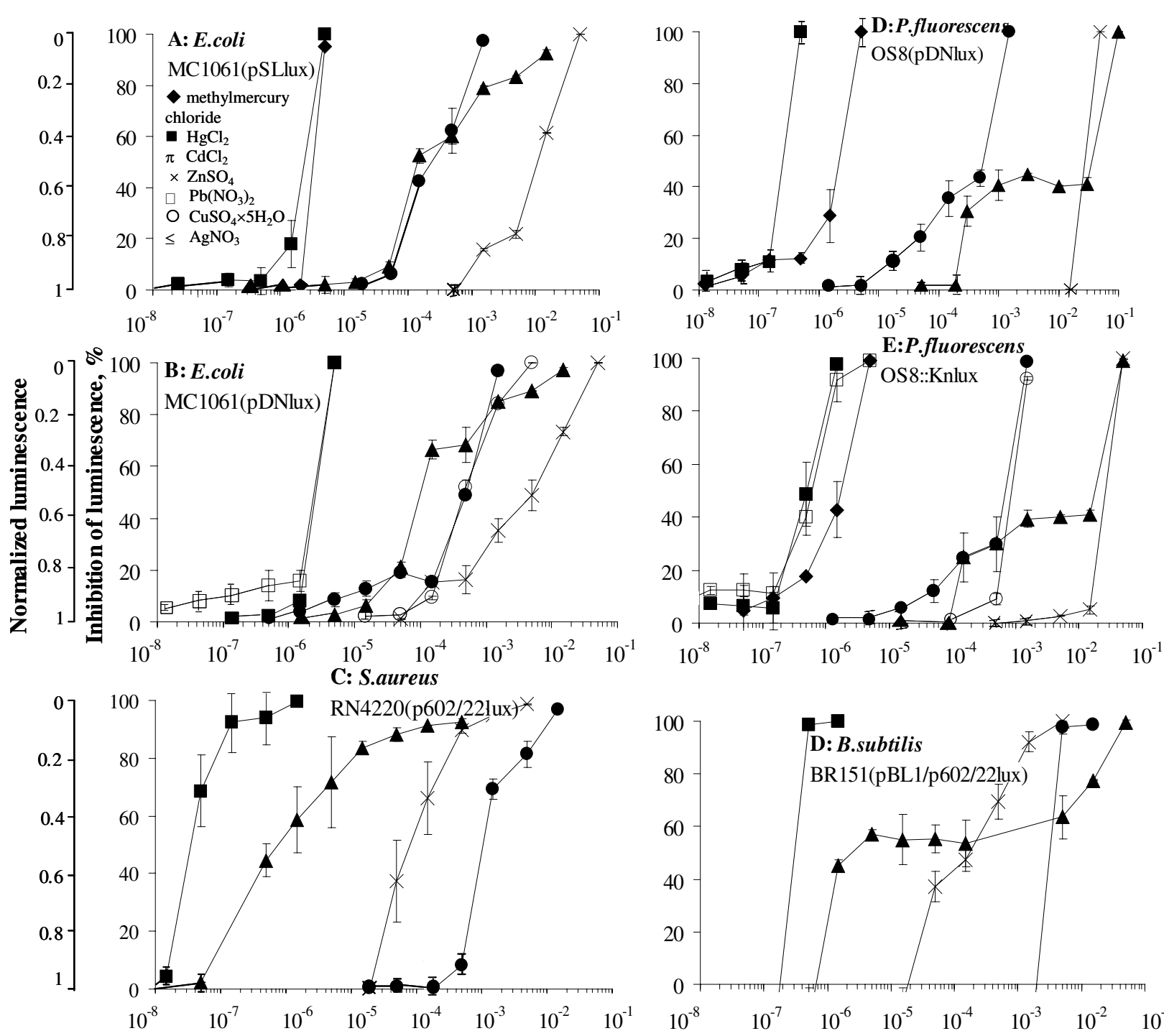

Concentration, $M$

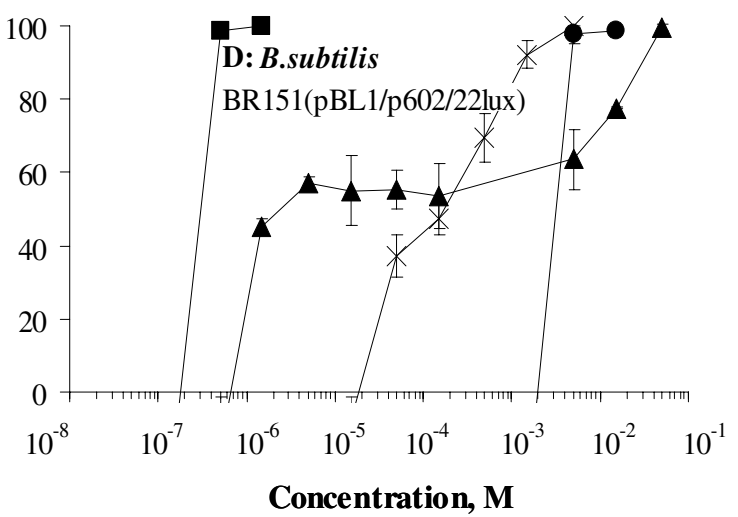

Figure 2

Toxicity of heavy metals for constitutively luminescent control strains. Toxicity of heavy metals is expressed as inhibition of bioluminescence or decrease in normalized luminescence after 2 hours incubation. Names of strains and symbols for heavy metals are indicated. Data represent mean \pm SD of three independent measurements. 2-h EC $_{50}$ values calculated from these curves are presented in Tables I-4.

B. subtilis BR151(pBL1/p602/22lux) in which the optimized luxCDABE [37] is under the lac promoter, were constructed (Table 4). However, analogously to earlier studies [38] the stability of the plasmids with genes encoding for bioluminescence was relatively poor in Gram-positive bacterial strains as frequent loss of plasmids especially in strains with higher background luminescence, was observed. Even, no transformants were obtained when plasmid p602/22lux was transformed into B. subtilis BR151. This problem was solved and the relative stability of the bioluminescence encoding genes was achieved when the plasmid was transformed to B. subtilis strain containing a helper plasmid pBL1 (expresses LacIrepressor) [38]. Toxicity (2-h EC $\mathrm{EC}_{50}$ values) of $\mathrm{Hg}^{2+}, \mathrm{Cd}^{2+}, \mathrm{Pb}^{2+}$ and $\mathrm{Zn}^{2+}$ to S. aureus RN4220(p602/22lux) and B. subtilis BR151(pBL1/p602/22lux) are presented in Table 4 and respective concentration-effect curves in Figure 2.

\section{Discussion}

We constructed a set of Gram-negative and Gram-positive bioluminescent bacterial sensors in which the luxCDABE genes are regulated either by metal-response elements 
Table 2: Characteristics of Pseudomonas fluorescens OS8-based plasmid-containing luminescent heavy metal sensors and toxicity control strains

\begin{tabular}{|c|c|c|c|c|}
\hline & \multicolumn{3}{|c|}{ Sensor strains } & \multirow{2}{*}{$\begin{array}{l}\text { Control strain } \\
\text { OS8(pDNlux) }\end{array}$} \\
\hline & $\begin{array}{l}\text { OS8(pDNmer } \mathbf{R}_{\mathrm{BS}} \mathbf{B} \\
\text { Pmerlux) }\end{array}$ & $\begin{array}{l}\text { OS8(pDNpbrR } \\
\text { PpbrAlux) }\end{array}$ & $\begin{array}{l}\text { OS8(pDNcadR } \\
\text { PcadAlux) }\end{array}$ & \\
\hline $\begin{array}{l}\text { Background } \\
\text { luminescence }^{\mathrm{a}}\end{array}$ & $1600 \pm 540$ & $3960 \pm 1300$ & $25900 \pm 8700$ & $64500 \pm 6600$ \\
\hline Maximum induction ${ }^{\mathrm{b}}$ & 200 & 7 & 6 & no induction \\
\hline $\begin{array}{l}\text { No of cells in the test } \\
(100 \mu \mathrm{l})\end{array}$ & $5 \times 10^{6}$ & $4 \times 10^{6}$ & $4 \times 10^{6}$ & $5 \times 10^{6}$ \\
\hline Compound & \multicolumn{3}{|c|}{ Limit of determination ${ }^{\mathrm{c}} /$ Toxicity $^{\mathrm{d}}, \mathrm{M}\left(\mathrm{mg}\right.$ of compound $\left.\mathrm{I}^{-1}\right)$} & $\begin{array}{c}\text { Toxicity }\left(2-\mathrm{hEC}_{50} \mathrm{e}\right), \mathrm{M}(\mathrm{mg} \\
\left.\text { of compound } \mathrm{I}^{-1}\right)\end{array}$ \\
\hline $\mathrm{HgCl}_{2}$ & $10^{-9}(0.0003) / 10^{-7}(0.04)$ & $10^{-7}(0.04) / 10^{-6}(0.4)$ & $10^{-7}(0.03) / 10^{-6}(0.4)$ & $2.5 \times 10^{-7}(0.07)$ \\
\hline $\mathrm{CH}_{3} \mathrm{HgCl}$ & $10^{-10}(0.00003) / 10^{-7}(0.04)$ & not tested & not tested & $2 \times 10^{-6}(0.5)$ \\
\hline $\mathrm{CdCl}_{2}$ & $5 \times 10^{-6}(0.9) / 10^{-2}(2740)$ & $8 \times 10^{-7}(0.2) / 5 \times 10^{-4}(92)$ & $6 \times 10^{-8}(0.01) / 10^{-4}(18)$ & $4 \times 10^{-2}(7300)$ \\
\hline $\mathrm{ZnSO}_{4}{ }^{\mathrm{f}}$ & No induction & $\begin{array}{c}4 \times 10^{-5}(6.4) / 5 \times 10^{-2} \\
(8050)\end{array}$ & $\begin{array}{c}8 \times 10^{-6}(1.3) / 3 \times 10^{-2} \\
(4800)\end{array}$ & $3 \times 10^{-2}(4800)$ \\
\hline $\mathrm{Pb}\left(\mathrm{NO}_{3}\right)_{2}$ & No induction & $9 \times 10^{-7}(0.3) / 10^{-3}(500)$ & $4 \times 10^{-7}(0.1) / 10^{-3}(500)$ & $7 \times 10^{-4}(230)$ \\
\hline $\mathrm{CuSO}_{4}{ }^{\mathrm{g}}$ & not tested & not tested & not tested & not tested \\
\hline $\mathrm{AgNO}_{3}$ & not tested & not tested & not tested & not tested \\
\hline
\end{tabular}

a luminescence (relative light units, RLU) of $100 \mu \mathrm{l}$ of bacterial suspension before the test as measured by plate luminometer Fluoroskan (ThermoLabsystems). Average of at least three assays

$\mathrm{b}$ as fold over the (non-induced) background

c see equation 4 in Methods

$d$ the lowest tested concentration causing a measurable decrease in the bioluminescence of the sensor strains (read from concentration-induction curves in Figure I)

e concentration causing $50 \%$ decrease in the bioluminescence production (calculated from Figure 2)

$f$ tested as $\mathrm{ZnSO}_{4} \times 7 \mathrm{H}_{2} \mathrm{O}$

$g$ tested as $\mathrm{CuSO}_{4} \times 5 \mathrm{H}_{2} \mathrm{O}$

("lights-on" metal sensors) or expressed in a constitutive manner ("lights-off" control strains). The developed set of bacterial sensors is original in several aspects:

- both Gram-negative (E. coli, P. fluorescens) and Gram-positive (S. aureus, B. subtilis) bacteria were used as hosts for heavy metal sensors and luxCDABE genes from Photorhabdus luminescens (thermostability > $30^{\circ} \mathrm{C}$ ) were used as a reporter system;

- this is the first paper on construction and characterization of Gram-positive lux-cassette expressing sensors for $\mathrm{Cd}, \mathrm{Hg}$, $\mathrm{Zn}$ and $\mathrm{Pb}$;

- when possible, similar metal-response elements were used in different bacterial hosts, to evaluate the effect of the host bacterium on the specificity and sensitivity of the constructed sensor;

- similar metal-response elements were expressed both in plasmid and in chromosome of $P$. fluorescens, to determine the effect of the copy number of the lux cassette-fused metal-response elements on the performance of the sensors;
- a constitutively luminescent control ("lights-off" construct) was constructed for each heavy metal sensor and used to account for unspecific effects of the samples on bacterial bioluminescence. These control bacteria can also be used for general toxicity testing.

\section{Properties of "lights-off" control strains}

The constitutively luminescent "lights-off" control strains had always higher background bioluminescence than the respective control strains (Tables 1, 2, 3, 4). The highest background luminescence (600 000 RLU) was measured for E. coli MC1061 (pSLlux) probably due to the location of the luxCDABE on a high-copy-number plasmid. As the rationale of including the control strains in the assay is to take into account the possible non-specific effects (e.g., toxicity) of the sample on bacterial bioluminescence, the high initial bioluminescence allowing more accurate measurement of the inhibition of bioluminescence, is certainly a bonus. By decreasing the plasmid copy number, the background bioluminescence of the "lights-off" strains clearly decreased. The bioluminescence of $E$. coli MC1061(pDNlux) containing a medium-copy-number plasmid was about 100 -fold lower than that of $E$. coli MC1061(pSLlux) (Table 1). The same trend was observed 
Table 3: Characteristics of Pseudomonas fluorescens OS8-based chromosomal luminescent heavy metal sensors and toxicity control strains

\begin{tabular}{|c|c|c|c|c|c|c|}
\hline & \multicolumn{5}{|c|}{ Sensor strains } & \multirow{2}{*}{$\begin{array}{c}\text { Control strain } \\
\text { OS8::Knlux }\end{array}$} \\
\hline & $\begin{array}{c}\text { OS8::Knmer } \mathbf{R}_{\mathrm{BS}} \mathbf{B} \\
\text { Pmerlux }\end{array}$ & $\begin{array}{c}\text { OS8::KncueRPco } \\
\text { pAlux }\end{array}$ & $\begin{array}{c}\text { OS8:: KnzntRPzn } \\
\text { tAlux }\end{array}$ & $\begin{array}{l}\text { OS8::KnpbrR } \\
\text { PpbrAlux }\end{array}$ & $\begin{array}{l}\text { OS8::KncadR } \\
\text { PcadAlux }\end{array}$ & \\
\hline $\begin{array}{l}\text { Background } \\
\text { luminescence }\end{array}$ & $1290 \pm 240$ & $1250 \pm 180$ & $3530 \pm 1570$ & $84 \pm 35$ & $2860 \pm 320$ & $600-1400^{b}$ \\
\hline $\begin{array}{l}\text { Maximum } \\
\text { inductionc }\end{array}$ & 400 & 7 & 20 & 50 & 80 & no induction \\
\hline $\begin{array}{l}\text { No of cells in } \\
\text { the test }(100 \mu \mathrm{l})\end{array}$ & $2 \times 10^{7}$ & $3 \times 10^{7}$ & $6 \times 10^{6}$ & $3 \times 10^{6}$ & $3 \times 10^{7}$ & $3 \times 10^{6}-3 \times 10^{7 b}$ \\
\hline Compound & \multicolumn{5}{|c|}{ Limit of determination $/$ Toxicity ${ }^{\mathrm{e}}, \mathrm{M}$ (mg of compound $\mathrm{I}^{-1}$ ) } & $\begin{array}{c}\text { Toxicity } \\
\left(2-\mathrm{EC}_{50}{ }^{\mathrm{f}}\right), \mathrm{M} \\
\left(\mathrm{mg} \text { compound } \mathrm{I}^{-1}\right)\end{array}$ \\
\hline $\mathrm{HgCl}_{2}$ & $\begin{array}{c}3 \times 10^{-9}(0.0008) / 5 \\
\times 10^{-6}(1.3)\end{array}$ & no induction & $\begin{array}{c}3 \times 10^{-7}(0.08) / 5 \times \\
10^{-6}(1.4)\end{array}$ & $\begin{array}{c}3 \times 10^{-8}(0.008) / \\
10^{-6}(0.4)\end{array}$ & $\begin{array}{c}2 \times 10^{-8}(0.005) / \\
10^{-6}(0.4)\end{array}$ & $5 \times 10^{-7}(0.14)$ \\
\hline $\mathrm{CH}_{3} \mathrm{HgCl}$ & $\begin{array}{c}3 \times 10^{-9}(0.0008) / 5 \\
\times 10^{-6}(1.3)\end{array}$ & not tested & not tested & not tested & not tested & $2 \times 10^{-6}(0.58)$ \\
\hline $\mathrm{CdCl}_{2}$ & $\begin{array}{c}5 \times 10^{-5}(9.2) / 5 \times \\
10^{-2}(9150)\end{array}$ & no induction & $\begin{array}{c}8 \times 10^{-8}(0.02) / 10^{-2} \\
(2750)\end{array}$ & $\begin{array}{c}8 \times 10^{-8}(0.02) / 5 \times \\
10^{-4}(92)\end{array}$ & $\begin{array}{c}3 \times 10^{-8}(0.006) / 5 \\
\times 10^{-3}(915)\end{array}$ & $2 \times 10^{-2}(3660)$ \\
\hline $\mathrm{ZnSO}_{4}{ }^{\mathrm{g}}$ & no induction & no induction & $\begin{array}{c}3 \times 10^{-5}(4.8) / 5 \times \\
10^{-2}(8050)\end{array}$ & $\begin{array}{c}2 \times 10^{-5}(3.2) / 10^{-2} \\
(2420)\end{array}$ & $\begin{array}{c}4 \times 10^{-6}(0.6) / 2 \times \\
10^{-2}(3220)\end{array}$ & $3.5 \times 10^{-2}(5640)$ \\
\hline $\mathrm{Pb}\left(\mathrm{NO}_{3}\right)_{2}$ & no induction & no induction & $\begin{array}{c}4 \times 10^{-7}(0.1) / 10^{-3} \\
(500)\end{array}$ & $\begin{array}{c}2 \times 10^{-7}(0.07) / 10^{-3} \\
(500)\end{array}$ & $\begin{array}{c}3 \times 10^{-7}(0.1) / 10^{-3} \\
(500)\end{array}$ & $7 \times 10^{-4}(231)$ \\
\hline $\mathrm{CuSO}_{4}{ }^{\mathrm{h}}$ & not tested & $\begin{array}{c}5 \times 10^{-5}(8) / 10^{-3} \\
(240)\end{array}$ & not tested & not tested & not tested & $8 \times 10^{-3}(1280)$ \\
\hline $\mathrm{AgNO}_{3}$ & not tested & no induction & not tested & not tested & not tested & $5 \times 10^{-7}(0.083)$ \\
\hline
\end{tabular}

a luminescence (relative light units, RLU) of $100 \mu \mathrm{l}$ of bacterial suspension before the test as measured by plate luminometer Fluoroskan

(ThermoLabsystems). Average of at least three assays

b cells at different optical densities (see Methods) yielded different RLU values and number of viable cells

$c$ as fold over the (non-induced) background

$\mathrm{d}$ see equation 4 in Methods

e the lowest tested concentration causing a measurable decrease in the bioluminescence of the sensor strains (read from concentration-induction curves in Figure I)

${ }^{f}$ concentration causing $50 \%$ decrease in the bioluminescence production (calculated from Figure 2)

$g$ tested as $\mathrm{ZnSO}_{4} \times 7 \mathrm{H}_{2} \mathrm{O}$

h tested as $\mathrm{CuSO}_{4} \times 5 \mathrm{H}_{2} \mathrm{O}$

for $P$. fluorescens as the background luminescence of OS8(pDNlux) (luxCDABE in about 10 copies) was about 100-fold higher than that of the OS::Knlux (a single copy of luxCDABE) (Tables 2 and 3 ). However, the background luminescence value did not affect the sensitivity of the "lights-off" strains to heavy metals: the $\mathrm{EC}_{50}$ values of differently luminescent $E$. coli and P. fluorescens control strains were similar (Tables 1, 2 and 3). Almost no effect of bioluminescence on bacterial sensitivity to heavy metals has also been demonstrated earlier by showing that a lux-marked Burkholderia sp. had similar sensitivity to Zn and $\mathrm{Cu}$ as the wild (not luminescent) strain in dehydrogenase assay [39]. In addition, we showed that the toxicity of $\mathrm{Hg}$, methylmercury, $\mathrm{Pb}$ and $\mathrm{Ag}$ to the both Gram-negative bacteria (E. coli and P. fluorescens) was similar. However, E. coli proved more sensitive than $P$. fluorescens towards Zn (about 3-fold), Cu (about 15-fold) and Cd (about 100-fold) (Tables 1, 2 and 3). Indeed, relatively low sensitivity of a Pseudomonas putida towards Cd (about 3 orders of magnitude lower than the sensitivity of E. coli) in a growth ihibition assay has been shown earlier [40].

Comparison of Gram-negative and -positive control strains showed that the luminescence of the latter was always lower (Tables 1, 2, 3, 4). This could be either due to the poor expression of bioluminescence-encoding genes in these strains or partial loss of lux-containing plasmid in the bacterial cultures. In addition, Gram-positive strains were remarkably more sensitive to the tested heavy metals than Gram-negative $\left(\mathrm{EC}_{50}\right.$ values in Tables 1, 2, 3, 4). Interestingly, other authors [41] have shown that the toxiciy of $\mathrm{Hg}$ was similar to E. coli and B. subtilis whereas we showed that the latter was at least 20 -fold more senistive than the former. 
Table 4: Characteristics of Staphylococcus aureus and Bacillus subtilis-based luminescent heavy metal sensors and toxicity control strains

\begin{tabular}{|c|c|c|c|c|}
\hline & \multicolumn{2}{|c|}{ Sensor strains } & \multicolumn{2}{|c|}{ Control strains } \\
\hline & $\begin{array}{l}\text { S. aureus RN4220 } \\
\text { (pcadCPcadAlux) }\end{array}$ & $\begin{array}{l}\text { B. subtilis BRI5I } \\
\text { (pcadCPcadAlux) }\end{array}$ & $\begin{array}{l}\text { S. aureus RN4220 (p602/ } \\
22 \text { lux })^{\mathrm{a}}\end{array}$ & $\begin{array}{l}\text { B. subtilis BRI5I (pBLI/ } \\
\text { p602/22lux) }\end{array}$ \\
\hline $\begin{array}{l}\text { Background } \\
\text { luminescence }\end{array}$ & $81 \pm 30$ & $84 \pm 30$ & $750 \pm 70$ & $120 \pm 40$ \\
\hline Maximum induction & 30 & 4 & no induction & no induction \\
\hline $\begin{array}{l}\text { No of cells in the test } \\
(100 \mu \mathrm{l})\end{array}$ & $10^{7}$ & $10^{7}$ & $10^{7}$ & $10^{7}$ \\
\hline Compound & \multicolumn{2}{|c|}{$\begin{array}{l}\text { Limit of determinatione/Toxicity }{ }^{\mathrm{f}}, \mathrm{M} \text { (mg of } \\
\left.\text { compound } \mathrm{I}^{-1}\right)\end{array}$} & \multicolumn{2}{|c|}{ Toxicity $\left(2-\mathrm{hEC}_{50^{\mathrm{g}}}\right), \mathrm{M}\left(\mathrm{mg}\right.$ of compound $\left.\mathrm{I}^{-1}\right)$} \\
\hline $\mathrm{HgCl}_{2}$ & $10^{-8}(0.003) / 5 \times 10^{-7}(0.1)$ & $\begin{array}{c}4 \times 10^{-8}(0.01) / 5 \times 10^{-7} \\
(0.1)\end{array}$ & $5 \times 10^{-8}(0.01)$ & $10^{-7}(0.04)$ \\
\hline $\mathrm{CdCl}_{2}$ & $4 \times 10^{-8}(0.007) / 10^{-5}(2.75)$ & $10^{-8}(0.002) / 10^{-7}(0.027)$ & $8 \times 10^{-7}(0.2)$ & $3 \times 10^{-6}(0.6)$ \\
\hline $\mathrm{ZnSO}_{4}^{\mathrm{h}}$ & $2 \times 10^{-5}(3.2) / 5 \times 10^{-4}(81)$ & $10^{-5}(1.6) / 10^{-4}(24)$ & $8 \times 10^{-5}(13)$ & $10^{-4}(22)$ \\
\hline $\mathrm{Pb}\left(\mathrm{NO}_{3}\right)_{2}$ & $10^{-7}(0.03) / 10^{-3}(500)$ & $10^{-7}(0.03) / 10^{-3}(500)$ & $10^{-3}(530)$ & $3 \times 10^{-3}(990)$ \\
\hline \multicolumn{5}{|c|}{$\begin{array}{l}\text { a control for RN4220(pcadCPcadAlux) } \\
\text { b control for BR5I (pcadCPcadAlux) } \\
\text { c luminescence (relative light units, RLU) of } 100 \mu \mathrm{l} \text { of bacterial suspension before the test as measured by plate luminometer Fluoroskan } \\
\text { (ThermoLabsystems). Average of at least three assays. } \\
\text { d as fold over the (non-induced) background } \\
\text { e see equation } 4 \text { in Methods } \\
\text { f the lowest tested concentration causing a measurable decrease in the bioluminescence of the sensor strains (read from concentration-induction } \\
\text { curves in Figure I) } \\
\text { g concentration causing } 50 \% \text { decrease in the bioluminescence production (calculated from Figure 2) } \\
\text { h tested as } \mathrm{ZnSO}_{4} \times 7 \mathrm{H}_{2} \mathrm{O}\end{array}$} \\
\hline
\end{tabular}

\section{Properties of heavy metal sensor strains: background luminescence}

Differently from "lights-off" constructs, in metal sensor strains the lower background luminescence is an advantage as it ensures a more pronounced induction at lower metal concentrations (in the case of a strain with high background luminescence this high value must be exceeded at least twice to be equivalent to LOD). Theoretically, the sensor strains should be bioluminescent (induced) only in the presence of intracellular heavy metals, which bind on the regulatory protein. However, background luminescence values in the sensor strains were also registered in the absence of added heavy metals (Tables 1, 2, 3, 4). The reason for this could be either the leakage of the promoter controlling the expression of luxgenes and/or as proposed by [42] metal impurities of the test medium. Indeed, the optimized medium used in our study (see Methods), contained trace amounts of $\mathrm{Cd}$ $\left(0.0001 \mathrm{mg} \mathrm{l}^{-1}\right), \mathrm{Zn}\left(0.035 \mathrm{mg} \mathrm{l}^{-1}\right), \mathrm{Cu}\left(0.0025 \mathrm{mg} \mathrm{l}^{-1}\right)$ and $\mathrm{Pb}\left(0.003 \mathrm{mg} \mathrm{l}^{-1}\right)$. However, these concentrations were more than 5-460-fold lower than the LODs of the sensors, depending on the strain (Tables 1, 2, 3, 4). Also, the background luminescence of the sensor strains (varying among the strains; Tables 1, 2, 3, 4) did not correlate with their sensitivities to the metals present as impurities in the test medium. Thus, the most probable reason for the background luminescence in the sensor strains is the leakage of the promoter controlling the expression of $\operatorname{luxCDABE}$ genes. Indeed, the E. coli MC1061(pmerR ${ }_{\mathrm{BS}}$ BPmerlux) had remarkably lower background than the other $E$. coli strains and it is well known that the regulatory protein in this sensor, MerR, is a strong repressor in the absence of mercury $[43,44]$. At the same time, the regulatory protein ZntR in MC1061(pSLzntR/pDNPzntAlux) strain with high background luminescence, has not been clearly shown to act as a repressor in the absence of zinc [29]. In addition to the nature of the metal-response elements, also the number of copies in which the lux-cassette and linked metal-response elements were present in the cells affected the background luminescence ( $P$. fluorescens plasmid-bearing versus chromosomal strains, Tables 2 and 3). As a rule, the higher the background luminescence the lower the maximum induction of the sensors (Tables 1, 2, $3,4)$. This could be due to the depletion of energy in the bacterial cells at high bioluminescence values as the emission of bioluminescence requires high amounts of cellular energy [45]. However, the background luminescence of the metal sensor strains did not affect their metal sensitivity (LOD) (Tables 1, 2, 3, 4). 


\section{Properties of heavy metal sensor strains: sensitivity and specificity}

The sensor strains were characterized for their sensitivity and specificity using selected environmentally relevant heavy metals. The induction of luminescence was measured after 2 hours incubation that was selected according to our optimization studies (T.Rõlova, personal communication) and similar studies by other authors [17]. Interestingly, only one of the sensors, $P$. fluorescens OS8::KncueRPcopAlux was single metal (Cu) specific (Figure 1J). The E. coli MC1061(pSLcueR/pDNPcopAlux) expressing similar metal-response elements was in addition to $\mathrm{Cu}$ induced also by Ag, but in relatively high (environmentally irrelevant) concentrations (Figure 1I). The sensors expressing Hg-response elements (E. coli

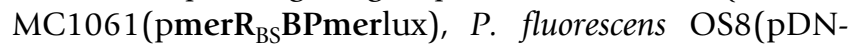
merR $_{\mathrm{BS}}$ BPmerlux) and OS8::KnmerR ${ }_{\mathrm{BS}}$ BPmerlux)) showed also relatively high specificity, by being induced only with inorganic and organic mercury compounds and Cd. However, induction with the latter occurred at concentrations 3-4 orders of magnitude higher than in the case of mercury and yielded remarkably lower inductions (Figure 1A-C). These data are in accordance with [46-48]. It is interesing to note that E. coli MC1061(pmerR BS $_{\text {BP- }}$ merlux) and $P$. fluorescens OS8(pDNmerR ${ }_{\mathrm{BS}} \mathrm{BPmerlux}$ were detecting methylmercury at about one order of magnitude lower concentrations than $\mathrm{HgCl}_{2}$ (Tables 1 and 2). Similar results for the same metal-response elements have been shown in [49] and is most probably caused by higher bioavailability of the organic mercury salt. On the other hand, both inorganic mercury and methylmercury were of similar toxicity to E. coli MC1061(pSLlux) or the latter was even less toxic to $P$. fluorescens control strains (Figure 2A), indicating that the elevated sensitivity towards methylated mercury occurs only at sub-toxic concentrations.

Sensor bacteria carrying the metal-response elements from Zn-resistance system of E. coli (E. coli MC1061(pSLzntR/pDNPzntAlux) and $P$. fluorescens OS8::KnzntRPzntAlux), Cd-resistance system from Pseudomonas putida (P. fluorescens OS8(pDNcadRPcadAlux) and OS8::KncadRPcadAlux), Pb-resistance system from Ralstonia metallidurans (P. fluorescens OS8(pDNpbrRPpbrAlux), OS8::KnpbrRPpbrAlux) or Cd-resistance system from $S$. aureus (S. aureus RN4220(pcadCPcadAlux) and B. subtilis BR151(pcadCPcadAlux)) responded to four of the selected seven heavy metal salts: $\mathrm{HgCl}_{2}, \mathrm{CdCl}_{2}, \mathrm{~Pb}\left(\mathrm{NO}_{3}\right)_{2}$ and $\mathrm{ZnSO}_{4}$ (Figure 1, Tables 1, 2, 3, 4) and the order of induction in all the cases was $\mathrm{Hg}^{2+} \approx \mathrm{Cd}^{2+}<\mathrm{Pb}^{2+}<\mathrm{Zn}^{2+}$. These unspecific responses were somewhat expected as earlier studies have shown similar results e.g. for Zn-resistance determinant from $E$. coli chromosome [14,50] and to our knowledge, no specific Cd-response system has been found. Unspecificity of several metal-response systems could be due to the evolution of these metal resistance systems to be induced by several heavy metals in order to detoxify them, or simply because the metal-binding proteins in these systems are unable to differentiate between different bi-valent metal ions [51].

Comparison of sensitivities of the current metal sensor strains with previously constructed ones (see below) showed that some of the current sensors were detecting very low levels of metals (lowest LOD values reported so far). However, variability of test results may occur between different papers due to different experimental conditions, which may affect the speciation and thus, bioavailability of metals. Nevertheless, our comparison showed that the strain E. coli MC1061(pSLcueR/pDNPcopAlux) detected 20-fold lower concentrations of $\mathrm{Cu}$ than similar previously published bacterial strains [11] and

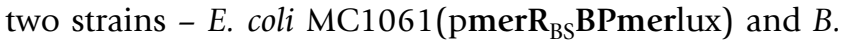
subtilis BR151(pcadCPcadAlux) - were similar in sensitivity with the most sensitive previously reported strains for $\mathrm{Hg}$ and $\mathrm{Cd}$, respectively $[10,11,16,52]$.

\section{Comparison of sensor constructs in different host bacteria} Performance of different types of recombinant bacteria carrying similar metal-response elements was compared. Comparison of the two Gram-negative host bacteria E. coli and $P$. fluorescens showed that the E. coli-based metal sensors were somewhat more sensitive. For example, E. coli MC1061(pSLcueR/pDNPcopAlux) was about 300-fold more sensitive to $\mathrm{Cu}$ than $P$. fluorescens OS8::KncueRPcopAlux and E. coli MC1061(pmerR BS $_{\text {BPmerlux) was }}$ induced by at least 10-fold lower concentrations of $\mathrm{Hg}^{2+}$, methylmercury and $\mathrm{Cd}^{2+}$ than $P$. fluorescens OS8(pDNmerR $_{\mathrm{BS}} \mathrm{BPmerlux}$ ). This and the lower toxicity of some heavy metals to $P$. fluorescens compared with E. coli could be explained by different cellular metal homeostasis (e.g., the presence and nature of metal transporters) of the host bacteria. Indeed, the effect of metal transporters on the sensitivity of bacterial heavy metal sensors has been shown [53]. On the other hand, there were no remarkable differences in LOD values of the two Gram-positive sensor strains S. aureus RN4220(pcadCPcadAlux) and B. subtilis BR151(pcadCPcadAlux) carrying similar metal-response elements (Table 4). Thus, differently from "lights-off" strains, the sensitivity of the "lights-on" sensors depends on the nature of the metal sensing element rather than on the bacterial host. Indeed, the strains with metal-response elements from $\mathrm{Hg}$ resistance system were the most sensitive to $\mathrm{Hg}$ and the least sensitive to $\mathrm{Cd}$ regardless of the host strain.

Different location of the metal-response elements in $P$. fluorescens (on a plasmid present in the cells in about 10 copies or as a single chosomosmal insertion) was chosen to clarify whether lowering the copy number of the metalresponse elements and $l u x$ genes will yield higher sensitivity, as previously shown for stress-induced bacterial 
strains [54]. However, our data on P. fluorescens with chromosomal insertions showed lower background luminescence but not higher sensitivity than the respective plasmid-containing strains (Figure 1B, C).

\section{Possible applications}

As shown above, all the constructed metal sensor strains showed concentration-dependent linear increase in bioluminescence at sub-toxic concentrations of heavy metals. Moreover, the increased bioluminescence of the sensor implies that the toxic metal has crossed the biological membrane and thus, has a potential to accumulate in the food chain. In addition, the limits of determination of most of the constructed sensors under our test conditions were low enough to detect even the EC permitted limit values for $\mathrm{Hg}$, $\mathrm{Cd}, \mathrm{Cu}$ and $\mathrm{Pb}$ in drinking water $(1,5,5000$ and $10 \mu \mathrm{g} \mathrm{l}^{-1}$, respectively; Directive 98/83 EC).

Currently the most challenging field of biosensor applications is the evaluation of bioavailable amounts of heavy metals in complex environmental matrices $[55,56]$ for risk assessment purposes. However, the use of microbial sensors for environmental analysis is currently restricted mostly due to the lack of specificity. This drawback may be overcome by the combined use of several strains with different specificities and sensitivities. In addition, $\mathrm{Cu}$ and $\mathrm{Zn}$-sensors have already proven very useful in other fields, e.g. in quantification of solubilized bioavailable metals from metal-containing nanoparticles [57-59].

\section{Conclusion}

As a result of this work, a battery of 19 recombinant luminescent bacterial strains was constructed which exhibits several novel aspects as it contains i) metal sensor strains with similar metal-response elements in different host bacteria; ii) metal sensor strains with metal-response elements in different copies and iii) a "lights-off" construct (control) for every constructed recombinant metal sensor strain. Thus, this set of sensors may be applicable for testing both, bioavailability of heavy metals and general toxicity.

\section{Methods \\ Construction of plasmids and strains}

Bacterial strains and plasmids used in this study are listed and their detailed characterization is provided in Additional file [see Additional file 1]. All the constructed sensors are based on components of heavy metal resistance systems (metal-response elements) and luxCDABE genes from Photorhabdus luminescens [60] (reporter).

\section{Gram-negative strains}

Escherichia coli-based sensors and the respective control strains Four new plasmids were constructed and electroporated [26] into E. coli MC1061 [61]. The obtained plasmid constructs were verified by multiple restriction analysis.
Plasmid pmer $\mathrm{R}_{\mathrm{BS}} \mathrm{BPmerlux}$ was constructed by ligating the 4600 bp BamHI-NheI-digested and Klenow-treated fragment of pmerR ${ }_{\mathrm{BS}}$ Bluc [49] and $3200 \mathrm{bp}$ EcoRI-XcmIdigested and T4-treated fragment of pTetlux [62].

Plasmid pDNPcopAlux was constructed by replacing the lucFF gene in pSLcueRPcopAluc [63] by luxCDABE genes. For that, $3900 \mathrm{bp}$ BamHI-NheI fragment of pSLcueRPcopAluc was ligated with a BamHI-NheI-digested PCR fragment of luxCDABE (primers: 5' TTAA GGA TCCG CAAATATGACTAAAAAAATT 3' and 5' ATATGCTAGCACTATCAAACGCTTCGGTTAA 3'; pmerR ${ }_{B S}$ BPmerlux was used as a template). The resulting plasmid pSLcueRPcopAlux was digested with NaeI and the fragment containing the promoter of $c o p A$ and the luxCDABE was inserted into BamHI-digested and Klenow-treated pDN18N [64]. The resulting plasmid pDNPcopAlux was electroporated into E. coli MC1061(pSLcueR) [63].

Plasmid pSLzntR was constructed by self-ligating the 3500 bp NgoMI fragment of pSLzntluc [50] containing the zntR gene. To construct pDNPzntAlux, first an intermediate pSLzntRPzntAlux was constructed by ligating the BamHI-NheI-digested pSLzntluc (containing the promoter of $z n t A$ ) and BamHI-NheI-digested PCR fragment of luxCDABE (see above). A NaeI fragment of pSLzntRPzntAlux containing the promoter of $z n t A$ and $l u x C D A B E$ genes was then ligated with BamHI-digested and Klenowtreated pDN18N [64] resulting in pDNPzntAlux. The plasmids pSLzntR and pDNPzntAlux were tandemly electroporated into E. coli MC1061 [61].

In addition to those four newly constructed plasmids, the previously constructed plasmids pSLlux and pDNlux [32] were electroporated into E. coli MC1061 to obtain control strains MC1061(pSLlux) and MC1061(pDNlux).

Pseudomonas fluorescens-based sensor and the respective control strains

Both, chomosomal insertion- and plasmid-containing strains of $P$. fluorescens OS8 were constructed.

\section{Plasmid-containing strains}

Altogether three new broad-host range sensor plasmids were constructed and electroporated into $P$. fluorescens OS8 [65] by standard methods [26]. The plasmid constructs were verified by multiple restriction analysis.

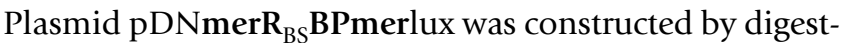
ing the pmerR ${ }_{\mathrm{BS}} \mathrm{BPmerlux}$ with PvuII and ligating with BamHI-digested and Klenow-treated pDN18N [64].

Plasmid pDNpbrRPpbrAlux was constructed by ligating the BamHI-XhoI-digested pSLlux [32] and BamHI-XhoIdigested 650 bp PCR product containing $p b r R$ and promoter of pbrA (primers: 5' ATATCTCGAGGGGAGCCT- 
TACCGGCAGAACAGCGA 3'and 5' TTAAGG ATCCCC TCATGGCAACCCCTTGTGTGTATTCA 3'; Ralstonia metallidurans $\mathrm{CH} 34$ cell extract prepared as in [50] was used as a template). The resulting plasmid pSLpbrRPpbrAlux was digested with PvuII-NaeI and ligated with BamHIdigested and Klenow-treated pDN18N [64] to obtain pDNpbrRPpbrAlux.

Plasmid pDNcadRPcadAlux was constructed by ligating the BamHI-BspEI-digested pSLlux [32] and BamHI-AgeIdigested 550 bp PCR fragment containing cadR and promoter of $c a d A$ (primers 5' ATATACCGGTAAGCTTTTGGCTTAATGCCCGTG 3' and 5' TTAA GGATC CCAT GGGGTCATCCTTAATTTGAGCC 3' were used; cell extract of Pseudomonas putida PaW85 prepared as in [50] was used as a template). The resulting plasmid pSLcadRPcadAlux was digested with XhoI-SalI, Klenow-treated and ligated with BamHI-digested and Klenow-treated pDN18N [64] to obtain pDNcadRPcadAlux.

The control strain OS8(pDNlux) was from [32].

\section{Strains with chromosomal insertions}

Chromosomal insertions were done by Tn 5 mini-transposonmutagenesis method [66]. Transposon-carrying suicide plasmids were constructed (see below) and transferred into the recipient strains by conjugation.

\section{Construction of suicide plasmids}

All suicide plasmids were constructed in the E. coli strain SY372 $\lambda$ pir [67] and were based on pTCR241 [68]. The pTCR241 was modified as follows: 1500 and 2500 bp NotI fragments between terminal ends of the Tn5 were removed and replaced by kanamycin resistance gene from pET26b (+) (Novagen) and the resulting plasmid was desginated pTCRKn.

For the construction of pTCRKnpbrRPpbrAlux, pTCRKnmerR $_{\mathrm{BS}} \mathrm{BPmerlux}$ and pTCRKnzntRPzntAlux, 6900, 8200 and 7000 bp PvuII fragments of pSLpbrRPpbrAlux, pmerR $_{B S}$ BPmerlux and pSLzntRPzntAlux and for the construction of pTCRKncadRPcadAlux and pTCRKncueRPcopAlux, 6750 and 6500 bp SalI-XhoI-digested and Klenowtreated fragments of pSLcadRPcadAlux and pSLcueRPcopAlux were inserted into StuI-site of pTCRKn situated between the terminal ends of the Tn 5 before the kanamycin resistance encoding gene. All the fragments inserted into pTCRKn contained respective metal-response elements and luxCDABE genes. For the construction of pTCRKnlux, an intermediate plasmid was constructed by inserting SalI-NruI fragment of pSLlux (luxCDABE genes under the lac promoter) into SalI-StuI-digested pSL1190. From the resulting plasmid a PvuII fragment (lac pro- moter and luxCDABE) was inserted into StuI-digested pTCRKn. The plasmid constructs were verified by multiple restriction analysis

\section{Chromosomal insertions to P. fluorescens OS8}

For chromosomal insertions, E. coli S17-1 $\lambda$ pir [69] was transformed with the appropriate suicide plasmid by $\mathrm{CaCl}_{2}$ method [26] to obtain the donor strains. The donor strain was grown overnight in LB medium (per liter: $10 \mathrm{~g}$ of tryptone, $10 \mathrm{~g}$ of $\mathrm{NaCl}, 5 \mathrm{~g}$ of yeast extract [26]) with $100 \mu \mathrm{g} \mathrm{ml}^{-1}$ of ampicillin and mixed with the overnight culture (in LB) of the recipient $P$. fluorescens OS8 at a ratio 1:2 (20 $\mu \mathrm{l}: 40 \mu \mathrm{l}) .5 \mathrm{ml}$ of $10 \mathrm{mM} \mathrm{MgSO}_{4}$ was added to the mixture and the cells were collected on a $0.45 \mu \mathrm{m}$ membrane filter. The filter was incubated on LB agar plate for 8-18 h to allow conjugation after which the cells on the filter were resuspended in $5 \mathrm{ml}$ of $10 \mathrm{mM} \mathrm{MgSO}_{4} .100-$ $500 \mu \mathrm{l}$ of the resulting mixture was plated onto selective M9 minimal medium (per liter: $6 \mathrm{~g}$ of $\mathrm{Na}_{2} \mathrm{HPO}_{4}, 3 \mathrm{~g}$ of $\mathrm{KH}_{2} \mathrm{PO}_{4}, 0.5 \mathrm{~g}$ of $\mathrm{NaCl}, 1 \mathrm{~g}$ of $\mathrm{NH}_{4} \mathrm{Cl}$ ) agar (1.5\%) plates supplemented with $4 \mathrm{~g} \mathrm{l}^{-1}$ of glucose and microelements (final concentration per liter: $26.9 \mathrm{mg}$ of $\mathrm{MgO}, 5 \mathrm{mg}$ of $\mathrm{CaCO}_{3}, 0.13 \mathrm{ml}$ of conc. $\mathrm{HCl}, 11.3 \mathrm{mg}$ of $\mathrm{FeSO}_{4} \times 7 \mathrm{H}_{2} \mathrm{O}$, $3.6 \mathrm{mg}$ of $\mathrm{ZnSO}_{4} \times 7 \mathrm{H}_{2} \mathrm{O}, 2.8 \mathrm{mg}$ of $\mathrm{MnSO}_{4} \times 4 \mathrm{H}_{2} \mathrm{O}, 0.65$ $\mathrm{mg}$ of $\mathrm{CuSO}_{4} \times 5 \mathrm{H}_{2} \mathrm{O}, 0.7 \mathrm{mg}$ of $\mathrm{CoSO}_{4} \times 7 \mathrm{H}_{2} \mathrm{O}, 0.15 \mathrm{mg}$ of $\mathrm{H}_{3} \mathrm{BO}_{3}$; the mixture was prepared as 400 -fold concentrate). Selectivity of the plates was obtained by supplementing the medium with $100 \mu \mathrm{g} \mathrm{ml}-1$ of kanamycin. Strains with chromosomal insertions of metal-response elements and luxCDABE genes from pTCRKnpbrRPpbrAlux, pTCRKnmerR ${ }_{\text {BS }}$ BPmerlux, pTCRKnzntRPzntAlux, pTCRKncadRPcadAlux and pTCRKncueRPcopAlux were designated as OS8::KnpbrRPpbrAlux, OS8::KnmerR ${ }_{\mathrm{BS}} \mathrm{BP}-$ merlux, OS8::KnzntRPzntAlux, OS8::KncadRPcadAlux and OS8::KncueRPcopAlux, respectively. The strain with chromosomal insertion of luxCDABE from pTCRKnlux was designated as OS8::Knlux.

\section{Gram-positive strains}

Plasmids pcadCPcadAlux and p602/22lux were constructed by inserting the SmaI-SpeI-digested 5700 bp lux$C D A B E$ from pSB2025 (translational signals before the genes have been optimized for Gram-positive bacteria) $[37,70]$ into NheI-BamHI-digested (BamHI-digested end was filled with Klenow fragment) pTOO24 [36] or p602/ 22 [71], respectively. The plasmid constructs were verified by multiple restriction analysis

For the construction of Gram-positive metal sensor and control strains, the plasmids pcadCPcadAlux and p602/ 22lux were inserted into Staphylococcus aureus RN4220 [72] and Bacillus subtilis BR151 [73] or BR151(pBL1) [38] by electroporation $[74,75]$. 


\section{Cultivation of bacteria}

The constructed strains were stored as frozen glycerol $(15 \%)$ stocks at $-70^{\circ} \mathrm{C}$. Prior to testing, bacteria were grown on LB [26] agar plates containing appropriate antibiotics (see below). For the test, bacteria were cultivated in $\mathrm{M} 9$ medium (per liter: $6 \mathrm{~g}$ of $\mathrm{Na}_{2} \mathrm{HPO}_{4}, 3 \mathrm{~g}$ of $\mathrm{KH}_{2} \mathrm{PO}_{4}$, $0.5 \mathrm{~g}$ of NaCl, $1 \mathrm{~g}$ of $\mathrm{NH}_{4} \mathrm{Cl}, 0.25 \mathrm{~g}$ of $\mathrm{MgSO}_{4} \times 7 \mathrm{H}_{2} \mathrm{O}, 0.01$ $\mathrm{g}$ of $\mathrm{CaCl}_{2}$; [26]) supplemented with glucose (final concentration $1 \mathrm{~g} \mathrm{l}^{-1}$ ) and acid hydrolysate of casein (cas-AA; LabM; final concentration $5 \mathrm{~g} \mathrm{l}^{-1}$ ), HMM medium (per liter: $8.4 \mathrm{~g}$ of MOPS at $\mathrm{pH} 7.2,3.7 \mathrm{~g}$ of $\mathrm{KCl}, 0.53 \mathrm{~g}$ of $\mathrm{NH}_{4} \mathrm{Cl}, 0.07 \mathrm{~g}$ of $\mathrm{MgSO}_{4} \times 7 \mathrm{H}_{2} \mathrm{O}, 0.21 \mathrm{~g}$ of glycerol-2phosphate, $0.0003 \mathrm{~g}$ of $\mathrm{FeCl}_{3} \times 6 \mathrm{H}_{2} \mathrm{O}$; all the components were prepared as 10 or 100 -fold concentrated stocks, filter-sterilized and stored at $+4{ }^{\circ} \mathrm{C}$ except for glycerol-2phosphate, which was stored at $-20^{\circ} \mathrm{C}$; [76]) supplemented with glucose (final concentration $1 \mathrm{~g} \mathrm{l}^{-1}$ ) and casAA (final concentration $5 \mathrm{~g} \mathrm{l}^{-1}$ ) or LB medium. The culture media were supplemented with antibiotics as follows:

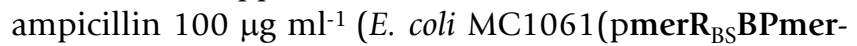
lux), MC1061(pSLlux)), ampicillin $100 \mu \mathrm{g} \mathrm{ml}^{-1}$ plus tetracycline $10 \mu \mathrm{g} \mathrm{ml} \mathrm{ml}^{-1}$ (E. coli MC106 (pSLcueR/ pDNPcopAlux), MC1061(pSLzntR/pDNPzntAlux)), tetracycline $10 \mu \mathrm{g} \mathrm{ml}^{-1}$ (MC1061(pDNlux)) and $20 \mu \mathrm{g} \mathrm{ml}^{-1}$

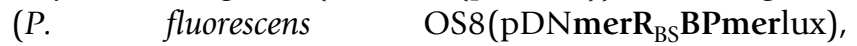
OS8(pDNpbrRPpbrAlux), OS8(pDNcadRPcadAlux), OS8(pDNlux)), kanamycin $50 \mu \mathrm{g} \mathrm{ml}^{-1}$ (S. aureus RN4220(pcadCPcadAlux), RN4220(p602/22lux) and $B$. subtilis BR151(pcadCPcadAlux)) or $100 \mu \mathrm{g} \mathrm{ml}^{-1}$ (P. fluorescens OS8::KnmerR ${ }_{B S}$ BPmerlux, OS8::KncueRPcopAlux, OS8::KnzntRPzntAlux, OS8::KnpbrRPpbrAlux, OS8::KncadRPcadAlux, OS8::Knlux), kanamycin $50 \mu \mathrm{g}$ $\mathrm{ml}^{-1}$ plus erythromycin $10 \mu \mathrm{g} \mathrm{ml}^{-1}$ (BR151(pBL1/p602/ 22lux)). All cultivations were performed on a shaker at $200 \mathrm{rpm}, 30^{\circ} \mathrm{C}$.

M9 medium with the above-mentioned supplements was used to cultivate E. coli and P. fluorescens strains when they were use to test $\mathrm{Cd}, \mathrm{Hg}$, methylmercury, $\mathrm{Zn}, \mathrm{Cu}$ or Ag. HMM medium with supplements was used to cultivate E. coli and $P$. fluorescens if they were used to test $\mathrm{Pb}$. The cultures in exponential phase $\left(\mathrm{OD}_{600}=0.6-0.8\right)$ were diluted with the respective test media until $\mathrm{OD}_{600} \sim 0.1$ except the four P. fluorescens strains with chromosomal insertions, which were cultivated until the $\mathrm{OD}_{600}$ of 0.8 (OS8::KncadRPcadAlux and OS8::KncueRPcopAlux), 0.4 (OS8::KnmerR ${ }_{\mathrm{BS}}$ BPmerlux) and 0.2 (OS8::KnzntRPzntAlux).

LB medium was used to cultivate $S$. aureus and B. subtilis strains. The cultures in exponential phase $\left(\mathrm{OD}_{600}=0.6-1\right)$ were then washed twice with either glucose and cas-AA supplemented M9 medium (further test with $\mathrm{Hg}$, $\mathrm{Zn}$ or Cd) or cas-AA and glucose-supplemented HMM (further test with $\mathrm{Pb}$ ) and diluted until $\mathrm{OD}_{600} \sim 0.1$. The number of bacterial cells in the test was determined for each strain before the test by spreading the appropriate dilutions of bacterial culture on antibiotic-containing LB agar plates and counting the colony forming units after 24 hours growth at $30^{\circ} \mathrm{C}$.

\section{Preparation of standard chemicals}

All heavy metal salts were at least of analytical grade (98\%): mercury (II) chloride $\left(\mathrm{HgCl}_{2}\right)$, methylmercury chloride $(\mathrm{MeHgCl})$, cadmium (II) chloride $\left(\mathrm{CdCl}_{2}\right)$, zinc (II) sulphate-7-hydrate $\left(\mathrm{ZnSO}_{4} \times 7 \mathrm{H}_{2} \mathrm{O}\right)$ and copper (II) sulphate-5-hydrate $\left(\mathrm{CuSO}_{4} \times 5 \mathrm{H}_{2} \mathrm{O}\right)$ were purchased from Riedel-de-Haën, lead (II) nitrate $\left(\mathrm{Pb}\left(\mathrm{NO}_{3}\right)_{2}\right)$ was from Fluka and silver (I) nitrate $\left(\mathrm{AgNO}_{3}\right)$ from J. T. Baker B.V. $1 \mathrm{M}$ stock solutions of $\mathrm{CdCl}_{2}, \mathrm{ZnSO}_{4} \times 7 \mathrm{H}_{2} \mathrm{O}$ and $\mathrm{CuSO}_{4}$ $\times 5 \mathrm{H}_{2} \mathrm{O}$ as well as $0.1 \mathrm{M}$ of $\mathrm{HgCl}_{2}, \mathrm{AgNO}_{3}$ and $\mathrm{Pb}\left(\mathrm{NO}_{3}\right)_{2}$ were prepared in MilliQ water. $0.1 \mathrm{M}$ stock solution of methylmercury chloride was prepared in DMSO. Before the induction measurements, serial dilutions of the stock solutions (geometrical factor 3.3) were done in MilliQ water.

\section{Measurements and calculations}

Serial dilutions of heavy metal standard solutions in MilliQ water were pipetted onto white 96-well Cliniplate (Thermo Labsystems, Helsinki, Finland) (100 $\mu \mathrm{l}$ per well), and an equal volume of the bacterial suspension (preparation escribed above) was added and the plates were incubated for $2 \mathrm{~h}$ at $30^{\circ} \mathrm{C}$ (optimal for the induction of bioluminescence in sensor cells) without shaking. After incubation, luminescence was measured with plate luminometer Fluoroskan (Thermo Labsystems). All the measurements with sensor and respective control bacteria were performed as three independent experiments in duplicate. To determine the background luminescence (non-affected by added metals) for each sensor and control strain, MilliQ water was added to bacterial suspension instead of metal dilutions ( 6 replicates).

Response of either metal sensor or control bacteria was expressed as normalised luminescence (NL) calculated as in [63] according to the following formula:

$$
N L=\frac{L_{S}}{L_{B}}
$$

where $L_{B}$ is the background luminescence (luminescence of bacteria without added heavy metal) and $L_{S}$ the metalaffected luminescence of the respective bacterium. The NL of the control strains could be used to correct the luminescence of the sensor stains in slightly toxic, coloured or turbid samples.

The limit of determination in NL values $\left(\mathrm{LOD}_{\mathrm{NL}}\right)$ for the sensor bacteria was determined in every assay as follows: 


$$
L O D_{N L}=2 \frac{\bar{X}_{B}+3 S D}{\bar{X}_{B}}
$$

where $\bar{X}_{B}$ is the mean background luminescence value of the sensor (minimum six blanks included in each assay) and SD is the standard deviation. The LOD as mg of metal $\mathrm{l}^{-1}$ was the metal concentration corespondng to $\mathrm{LOD}_{\mathrm{NL}}$ in the calibration curve.

In the case of the control strains, the inhibition of luminescence by metals was calculated by the following formula:

$$
\operatorname{Inhibition}(\%)=100 \frac{L_{B}-L s}{L_{B}}
$$

The 2-h $\mathrm{EC}_{50}$ (concentration of metal causing 50\% decrease in luminescence during 2 hours of exposure) was calculated from concentration-effect curves using log-normal regression.

\section{Authors' contributions}

AI was active in planning of the study, carried out most of the molecular genetic studies and supervised the calibration of sensors. She also drafted the manuscript.

TR carried out transposonmutagenesis and calibration of sensors

AK participated in the planning of the work concerning general toxicity, in coordination and in revision of the manuscript.

\section{Additional material}

\section{Additional file 1}

Strains and plasmids used in this study. Relevant characteristics of the bacterial strains and plasmids used in this study are provided.

Click here for file

[http://www.biomedcentral.com/content/supplementary/14726750-9-41-S1.doc]

\section{Acknowledgements}

Financial Support from Estonian Ministry of Science and Education (targeted funding project SF0690063s08), Maj and Tor Nessling Foundation, Estonian Science Foundation (grants no 6956, 6974 and Parrot program), Academy of Finland and World Federation of Scientists is acknowledged. Marko Virta is thanked for his contribution in planning of the molecular part of the study. Kaisa Hakkila, Piia Leskinen, Pekka Virtanen, Maret Koor and Roman Boroznjak are thanked for their help in experiments, Margit Heinlaan and Villem Aruoja are thanked for correcting the English of the manuscript. Victor de Lorenzo is thanked for the plasmid PTCR24I, Philip J. Hill for the plasmid pSB2035 and Martin Romantshuk for Pseudomonas fluorescens OS8. We thank the referees of this manuscript for impoving the paper considerably.

\section{References}

I. Kahru A: Ecotoxicological tests in non-ecotoxicological research: contribution to 3Rs. Use of luminescent photobacteria for evaluating the toxicity of 47 MEIC reference chemicals. ALTEX 2006, 23:302-308.

2. Kahru A, Põllumaa L: Environmental hazard pf the waste streams of the Estonian oil-shale industry: an ecotoxicological review. Oil Shale 2006, 23(I):53-93.

3. Parvez S, Venkataraman C, Mukherji S: A review on advantages of implementing luminescence inhibition test (Vibrio fischeri) for acute toxicity prediction of chemicals. Environment International 2006, 32:265-268.

4. Daunert S, Barrett G, Feliciano JS, Shetty R, Shrestha S, Smith-Spencer W: Genetically engineered whole-cell sensing systems: coupling biological recognition with reporter genes. Chem Rev 2000, I00(7):2705-2738.

5. King JMH, DiGrazia PM, Applegate B, Burlage R, Sanseverino J, Dunbar P, Larimer F, Sayler GS: Rapid, sensitive bioluminescent reporter technology for naphthalene exposure and biodegradation. Science 1990, 249:778-8I.

6. Geiselhart L, Osgood M, Holmes DS: Construction and evaluation of a self-luminescent biosensor. Ann N Y Acad Sci 1991, 646:53-60.

7. Köhler S, Belkin S, Schmid RD: Reporter gene bioassays in environmental analysis. Fresenius J Anal Chem 2000, 366:769-779.

8. Corbisier P, Lelie D van der, Borremans B, Provoost A, de Lorenzo V, Brown NL, Lloyd JR, Hobman JL, Csöregi E, Johansson G, Mattiasson B: Whole cell- and protein-based biosensors for the determination of bioavailable heavy metals in environmental samples. Anal Chim Acta 1999, 387:235-244.

9. Selifonova O, Burlage R, Barkay $T$ : Bioluminescent sensors for detection of bioavailable $\mathrm{Hg}$ (II) in the environment. Appl Environ Microbiol 1993, 59(9):3083-3090.

10. Tescione L, Belfort G: Construction and evaluation of a metal ion biosensor. Biotechnol Bioeng 1993, 42:945-952.

II. Hansen LJ, Sorensen S]: Versatile biosensor vectors for detection and quantification of mercury. FEMS Microbiol Lett 2000, 193: I23-127.

12. Omura T, Kiyono M, Pan-Hou H: Development of a sepcific and sensitive bacteria sensor for detection of mercury at picomolar levels in environment. Journal of Health Science 2004, 50(4):379-383.

13. Tibazarwa C, Corbisier P, Mench M, Bossus A, Solda P, Mergeay M, Wyns L, Lelie D van der: A microbial biosensor to predict bioavailable nickel in soil and its transfer to plants. Environ Pollut 200 I, I I 3:19-26.

14. Riether KB, Dollard MA, Billard P: Assessment of heavy metal bioavailability using Escherichia coli zntAp::lux and copAp::lux-based biosensors. Appl Microbiol Biotechnol 200I, 57(5-6):7|2-7|6

15. Brandt KK, Holm PE, Nybroe O: Bioavailability and toxicity of soil particle-associated copper as determined by two bioluminescent Pseudomonas fluorescens biosensor strains. Environ Toxicol Chem 2006, 25(7): I738-I74I.

16. Hakkila K, Maksimow M, Karp M, Virta M: Reporter genes lucFF, luxCDABE, gfp and dsred have different characteristics in whole-cell bacterial sensors. Anal Biochem 2002, 30 I (2):235-242.

17. Rasmussen LD, Sorensen S], Turner RR, Barkay T: Application of a mer-lux biosensor for estimating bioavailable mercury in soil. Soil Biol Biochem 2000, 32:639-46.

18. Heitzer A, Applegate B, Kehrmeyer S, Pinkart H, Webb OF, Phelps TJ, White DC, Sayler GS: Physiological considerations of environmental applications of lux reporter fusions. J Microbiol Methods 1998, 33:45-57.

19. Petänen T, Virta M, Karp M, Romantschuk M: Construction and use broad host range mercury and arsenite sensor plasmids in the soil bacterium Pseudomonas fluorescens OS8. Microb Ecol 200I, 4 I (4):360-368.

20. Tauriainen S, Virta M, Chang W, Karp M: Detecting bioavailable toxic metals and metalloides from natural water samples 
using luminescent sensor bacteria. Water Res 2000, 34:266I-2666.

21. Ivask A, Francois M, Kahru A, Dubourguier HC, Virta M, Douay F: Recombinant luminescent bacterial sensors for the measurement of bioavailability of cadmium and lead in soils polluted by metal smelters. Chemosphere 2004, 55:147-156.

22. Kahru A, Ivask A, Kasemets K, Põllumaa L, Kurvet I, Francois M, Dubourguier HC: Biotests and biosensors in ecotoxicological risk assessment of field soils polluted with zinc, lead and cadmium. Environ Toxicol Chem 2005, 24(I I ):2973-2982.

23. Peltola $\mathrm{P}$, Ivask A, Åström M, Virta M: Lead and $\mathrm{Cu}$ in contaminated urban soils: Extraction with chemical reagents and bioluminescent bacteria and yeast. Sci Total Environ 2005 350(I-3): 194-203.

24. Ivask A, Green T, Polyak B, Mor A, Kahru A, Virta M, Marks R: Fibreoptic bacterial biosensors and their application for the analysis of bioavailable $\mathrm{Hg}$ and $\mathrm{As}$ in soils and sediments from Aznalcollar mining area in Spain. Biosens Bioelectron 2007 22:1396-1402

25. Blattner FR, Plunkett G 3rd, Bloch CA, Perna NT, Burland V, Riley M, Collado-Vides J, Glasner JD, Rode CK, Mayhew GF, Gregor J, Davis NW, Kirkpatrick HA, Goeden MA, Rose DJ, Mau B, Shao Y: The complete genome sequence of Escherichia coli K-12. Science 1997, 277:| $453-147$

26. Sambrook J, Fritsch EF, Maniatis T: Molecular cloning. A laboratory manual New York: Cold Spring Harbour Laboratory Press; 1989.

27. Griffin HG, Foster TJ, Silver S, Misra TK: Cloning and DNA sequence of the mercuric- and organomercurial-resistance determinants of plasmid pDU 1358. Proc Natl Acad Sci USA 1987, 84:3||2-3||6.

28. Stoyanov JV, Hobman JL, Brown NL: CueR (Ybbl) of Escherichia coli is a MerR family regulator controlling expression of the copper exporter CopA. Mol Microbiol 200I, 39(2):502-5I I.

29. Brocklehurst KR, Hobman JL, Lawley B, Blank L, Marshall SJ, Brown NL, Morby AP: ZntR is a Zn(II)-responsive MerR-like transcriptional regulator of zntA in Escherichia coli. Mol Microbiol 1999 31:893-902.

30. Paton GI, Campbell CD, Glover AL, Killham K: Assessment of bioavailability of heavy metals using lux modified constructs of Pseudomonas fluorescens. Lett Appl Microbiol 1995, 20:52-56.

31. Tom-Petersen A, Hosbond C, Nybroe O: Identification of copperinduced genes in Pseudomonas fluorescens and use of a reporter strain to monitor bioavailable copper in soil. FEMS Microbiol Ecol 200I, 38:59-67.

32. Leedjärv A, lvask A, Virta M, Kahru A: Analysis of bioavailable phenols from natural samples by recombinant luminescent bacterial sensors. Chemosphere 2006, 64(II):1910-1919.

33. Borremans B, Hobman JL, Provoost A, Brown NL, Lelie D van der: Cloning and functional analysis of the pbr lead resistance determinant of Ralstonia metallidurans CH34. J Bacteriol 200 I, I 83:565I-5658.

34. Lee SW, Glickmann E, Cooksey DA: Chromosomal locus for cadmium resistance in Pseudomonas putida consisting of a cadmium-transporting ATPase and a MerR family response regulator. Appl Environ Microbiol 200I, 67: 1437-1444.

35. Lampinen J, Virta M, Karp M: Comparison of gram-positive and gram-negative bacterial strains cloned with different types of luciferase genes in bioluminescence cytotoxicity tests. Environ Toxicol Water Qual 1995, 10:157-166.

36. Tauriainen S, Karp M, Chang W, Virta M: Luminescent bacterial sensor for cadmium and lead. Biosens Bioelectron 1998 13:931-938.

37. Qazi SNA, Counil E, Morrissey J, Rees CED, Cockayne A, Winzer K, Chan WC, Williams P. Hill P: agr expression precedes escape of internalized Staphylococcus aureus from the host endosome. Infect Immun 200 I, 69(I I):7074-7082.

38. Lampinen J, Koivisto L, Wahlsten M, Mäntsälä P, Karp M: Expression of luciferase genes from different origins in Bacillus subtilis. Mol Gen Genet 1992, 232:498-504.

39. Chinalia FA, Paton GI, Killham KS: Physiological and toxicological characterization of an engineered whole-cell biosensor. Bioresour Technol 2008, 99:7|4-72।.

40. Leedjärv A, Ivask A, Virta M: The interplay of different transporters in the mediation of divalent heavy metal resistance in Pseudomonas putida KT2440. J Bact 2008, 190(8):2680-2689.
4I. Lampinen J, Virta M, Karp M: Comparison of gram positive and gram negative bacterial strains cloned with different types of luciferase genes in bioluminescence cytotoxicity tests. Environ Toxicol Water Qual 1995, I0(2): I57-166.

42. Outten FW, Outten CE, Hale J, O'Halloran TV: Transcriptional activation of an Escerichia coli copper efflux regulon by the chromosomal MerR homologue, CueR. I Biol Chem 2000, 275:31024-31029.

43. Lund PA, Ford S], Brown NL: Transcriptional regulation of the mercury-resistance genes of transposon Tn50 I. J Gen Microbiol 1986, 132(2):465-80

44. O'Halloran TV, Frantz B, Shin MK, Ralston DM, Wright JG: The MerR heavy metal receptor mediates positive activation in a topologically novel transcription complex. Cell 1989, 56:119-129.

45. Wilson T, Hastings JW: Bioluminescence. Annu Rev Cell Dev Biol 1998, 14:197-230.

46. Virta M, Lampinen J, Karp M: A luminescence-based mercury biosensor. Anal Chem 1995, 67(3):667-69.

47. Ralston $D$, O'Halloran TV: Ultrasensitivity and heavy-metal selectivity of the allosterically modulated MerR transcripion conplex. Proc Natl Acad Sci USA 1990, 87:3846-3850.

48. Golding GR, Sparling R, Kelly CA: Effect of $\mathbf{p H}$ in intracellular accumulation of trace concentrations of $\mathrm{Hg}$ (II) in Escherichia coli under aerobic conditions as measured using a mer-lux bioreporter. Appl Environ Microbiol 2008, 74(3):667-675.

49. Ivask $A$, Hakkila $K$, Virta M: Detection of organomercurials with whole-cell bacterial sensors. Anal Chem 200I, 73:5I68-5I7I.

50. Ivask $A$, Virta $M$, Kahru $A$ : Construction and use of specific luminescent recombinant bacterial sensors for the assessment of bioavailable fraction of cadmium, zinc, mercury and chromium in the soil. Soil Biol Biochem 2002, 34:1439-1447.

5I. Nies DH: Bacterial transition metal homeostasis. In Molecular microbiology of heavy metals Volume 6. Edited by: Nies DH, Silver S. Springer-Verlag, Berlin, Germany; 1007:1 18-142.

52. Rasmussen LD, Turner RR, Barkay T: Cell-density-dependent sensitivity of a mer-lux bioassay. Appl Environ Microbiol 1997. 63(8):329l-3.

53. Leedjärv A, Ivask A, Kahru A, Virta M: Improvement of bacterial bioreporters to detect zinc, cadmium and lead in environmental samples. Proceedings of Eight Finnish Conference of Environmental Sciences, Mikkeli 2008:322-325.

54. Van Dyk TK, Wei Y, Hanafey MK, Dolan M, Reeve MJK, Rafalski JA, Rothman-Denes LB, LaRossa RA: A genomic approach to gene fusion technology. Proc Natl Acad Sci USA 200I, 98(5):2555-2560.

55. Harms H, Wells M, Meer JR van der: Whole-cell living biosensors - are they ready for environmental application? Appl Microbiol Biotechnol 2006, 70(3):273-280.

56. Kahru A, Ivask A, Kasemets $K$, Põllumaa $L$, Kurvet $I$, François $M$, Dubourguier HC: Biotests and biosensors in ecotoxicological risk assessment of field soils polluted with zinc, lead and cadmium. Environ Toxicol Chem 2005, 24(I I):2973-2982.

57. Heinlaan M, Ivask A, Blinova I, Dubourguier HC, Kahru A: Toxicity of nanosized and bulk $\mathrm{ZnO}, \mathrm{CuO}$ and $\mathrm{TiO}_{2}$ to bacteria Vibrio fischeri and crustaceans Daphnia magna and Thamnocephalus platyurus. Chemosphere 2008, 7|(7):|308-1316.

58. Kahru A, Dubourguier HC, Blinova I, Ivask A, Kasemets K: Biotests and biosensors for ecotoxicology of metal oxide nanoparticles: A minireview. Sensors 2008, 8:5I53-5I70.

59. Aruoja $\mathrm{V}$, Dubourguier H-C, Kasemets K, Kahru A: Toxicity of nanoparticles of $\mathrm{CuO}, \mathrm{ZnO}$ and $\mathrm{TiO}_{2}$ to microalgae Pseudokirchneriella subcapitata. Sci Total Environ 2009, 407(4): | 46|-| 468.

60. Frackman $\mathrm{S}$, Anhalt $\mathrm{M}$, Nealson $\mathrm{KH}$ : Cloning, organization, and expression of the bioluminescence genes of Xenorhabdus luminescens. J Bacteriol 1990, 172:5767-5773.

61. Casadaban MJ, Cohen SN: Analysis of gene control signals by DNA fusion and cloning in Escherichia coli. J Mol Biol 1980, I38: 179-207.

62. Korpela MT, Kurittu JS, Karvinen JT, Karp MT: A recombinant Escherichia coli sensor strain for the detection of tetracyclines. Anal Chem 1998, 70:4457-4462.

63. Hakkila K, Green T, Leskinen P, Ivask A, Marks R, Virta M: Detection of bioavailable heavy metals in EILATox-Oregon samples using whole-cell luminescent bacterial sensors in suspension or immobilized onto fibre-optic tips. I Appl Toxicol 2004 24:333-342. 
64. Nunn D, Bergman S, Lory S: Products of three accessory genes, pilB, pilC, and pilD, are required for biogenesis of Pseudomonas aeruginosa pili. J Bacteriol 1990, 172:29|1-2919.

65. Sarand I, Haario H, Jorgenson KS, Romantshuk M: Effect of inoculation of a TOL plasmid containing mycorrhizosphere bacterium on development of Scots pine seedlings, their mycorrhizosphere and the microbial flora in $\mathrm{m}$-toluateamended soil. FEMS Microbiol Ecol 2000, 31:127-I4I.

66. de Lorenzo V, Timmis KN: Analysis and construction of stable phenotypes in gram-negative bacteria with Tn5- and TnI0derived minitransposons. Methods Enzymol 1994, 235:386-405.

67. Miller VL, Mekalanos Jl: A novel suicide vector and its use in construction of insertion mutations: osmoregulation of outer membrane proteins and virulence determinants in Vibrio cholerae requires toxR. I Bacteriol 1988, I 70:2575-2583.

68. Cebolla A, Ruiz-Berraquero F, Palomares AJ: Stable tagging of Rhizobium meliloti with the firefly luciferase gene for environmental monitoring. Appl Environ Microbiol I993, 59:25I I-25I9.

69. Simon R, Priefer UB, Puhler A: A broad host range mobilization system for in vivo genetic engineering: Transposon mutagenesis in Gram-negative bacteria. Biotechnology 1983, I:784-79|.

70. Immonen N Karp M: Bioluminescence-based bioassays for rapid detection of nisin in food. Biosens Bioelectron 2007, 22(910): 1982-1987.

7I. LeGrice SF], Beuck V, Mous J: Expression of biologically active human T-cell lymphotrophic virus type III reverse transcriptase in Bacillus subtilis. Gene 1987, 55:95-103.

72. Kreiswirth BN, Lofdahl S, Betley MJ, O'Reilly M, Schlievert PM, Bergdoll MS, Novick RP: The toxic shock syndrome exotoxin structural gene is not detectably transmitted by a prophage. Nature 1983, 305:709-7/2.

73. Young FE, Smith C, Reilly BE: Chromosomal location of genes regulating resistance to bacteriophage in Bacillus subtilis. Bacteriol 1969, 98:1087-1097.

74. Schenk S, Laddaga RA: Improved method for electroporation of Staphylococcus aureus. FEMS Microbiol Lett 1992, 73:133-I38.

75. Harwood CR, Cutting SM, (Eds): Molecular Biological Methods for Bacillus John Wiley \& Son Ltd; 1990.

76. LaRossa RA, Smulski DR, VanDyk TK: Interaction of lead nitrate and cadmium chloride with Escherichia coli K-I 2 and Salmonella typhimurium global regulatory mutants. I Ind Microbiol I995, I 4:252-258.

Publish with BioMed Central and every scientist can read your work free of charge

"BioMed Central will be the most significant development for disseminating the results of biomedical research in our lifetime. "

Sir Paul Nurse, Cancer Research UK

Your research papers will be:

- available free of charge to the entire biomedical community

- peer reviewed and published immediately upon acceptance

- cited in PubMed and archived on PubMed Central

- yours - you keep the copyright
BioMedcentral 